\title{
COMBINED UNCOVERED SHEET-AND-TUBE PVT- COLLECTOR SYSTEM WITH BUILT-IN STORAGE WATER HEATER
}

\author{
KH. S. KARIMOV ${ }^{1,2}$ AND MUHAMMAD ABID ${ }^{1}$ \\ ${ }^{1}$ GIK Institute of Engineering Sciences and Technology, Topi, Pakistan. \\ ${ }^{2}$ S.U.Umarov Physical Technical Institute of Academy of Sciences, Dushanbe, Tajikistan.
}

khasan@giki.ed.pk,abid@giki.edu.pk

\begin{abstract}
This work describes the design and investigation of a simple combined uncovered sheet-and-tube photo-voltaic-thermal (PVT) collector system. The PVTcollector system consists of a support, standard PV module $(1.22 \times 0.305 \mathrm{~m}$, area $=0.37 \mathrm{~m}^{2}$, fill factor $=0.75$ ), sheet-and-tube water collector and storage tank-heater. The collector was fixed under PV module. Inclination angle of the PVT-collector to the horizontal plane was 45 degree. The storage tank-heater played double role i.e. for storage of hot water and for water heating. The PVT-collector system could work in the fixed and tracking modes of operation. During investigations of PVT-collector in natural conditions, solar irradiance, voltage and current of PV module, ambient temperature and water temperature in storage tank were measured. Average thermal and electrical powers of the PVT-collector system at the tracking mode of operation observed were $39 \mathrm{~W}$ and $21 \mathrm{~W}$, with efficiencies of $15 \%$ and $8 \%$ respectively at the input power of $260 \mathrm{~W}$. The maximum temperature of the water obtained was $42{ }^{\circ} \mathrm{C}$. The system was observed efficient for low-temperature applications. The PVT-collector system may be used as a prototype for design of PVT-collector system for domestic application, teaching aid and for demonstration purposes.
\end{abstract}

ABSTRAK: Kerja ini menerangkan reka bentuk dan penyiasatan sebuah sistem pengumpul berbentuk helaian dan tiub foto voltan (PVT) yang mudah. Sistem pengumpul PVT terdiri dari alat sokongan, modul PV standard $(1,22 \times 0,305 \mathrm{~m}$, kawasan $=0.37 \mathrm{~m} 2$, faktor isi $=0.75$ ), sistem pengumpul dan pemanas air berbentuk helaian dan tiub. Sistem pemungut diletakkan di bawah modul PV. Sudut kecondongan pengumpul PVT satah mengufuk adalah 45 darjah. Tangki penyimpanan memainkan dua peranan, iaitu sebagai tempat menyimpan dan memanaskan air. Sistem PVT-pengumpul boleh bekerja dalam mod tetap dan juga mod pengesanan. Dalam kajian ini, kelakuan PVT pemungut-dalam keadaan semulajadi, sinaran suria, voltan dan sekarang PV modul, suhu ambien dan suhu air di dalam tangki simpanan telah diukur. Purata haba dan kuasa elektrik sistem PVT-pemungut pada mod pengesanan operasi yang diukur adalah $39 \mathrm{~W}$ dan $21 \mathrm{~W}$, dan kecekapan masing-masing adalah $15 \%$ dan $8 \%$ pada kuasa input $260 \mathrm{~W}$. Suhu maksima air yang diperolehi ialah $42{ }^{\circ} \mathrm{C}$. Sistem ini berkesan pada suhu-suhu rendah. Sistem PVT-pengumpul ini sesuai digunakan sebagai prototaip bagi reka bentuk sistem PVT-pemungut untuk aplikasi domestik, alat pengajaran dan untuk tujuan demonstrasi.

KEYWORDS: combined system; module; collector; storage water-heater 
Kh. S. Karimov and M. Abid

\section{INTRODUCTION}

Utilization of solar energy, which is environment-friendly, is very important for the sustainable development. As is known that one of the limiting factors of solar modules and collectors applications in especially urban area is the availability of the required sufficient land [1,2], therefore, during the last years, combined photo-voltaic-thermal collectors' designs were implemented and investigated in practice [3-12]. The main advantage of the PVT-collector system observed is to produce more electrical and thermal energy in comparison to the conventional PV modules and collectors that partially cover the same area. In addition, in comparison to separate thermal and PV system, the PVT-collectors provides architectural uniformity, reduce installation cost [13]. Basically four groups of water type PVT-collectors namely: sheet-and-tube PVT-collectors, channel PVTcollectors, free flow PVT-collectors and two-absorber PVT-collectors were evaluated and optical and thermal efficiencies of the PVT-collectors were calculated [13]. Except of the uncovered PVT-collector all discussed designs with additional glass sheet bring more reflection losses and less electrical efficiency of the system. It is also concluded in [13] that the uncovered PVT-collector for low temperature applications is most promising design. Table 1 shows transmission-absorption factors for the various design concepts (AM 1.5 spectrum) of sheet-and-tube PVT-collectors. $\tau_{\alpha}, \tau_{\alpha \mathrm{w}}$ and $\tau_{\mathrm{pv}}$ are transmissionabsorption coefficients of PVT-collector, water and PV-module respectively [13].

Maximum $\tau_{\mathrm{pv}}$ is observed for the uncovered PVT-collector showing potentially highest output electric energy in comparison to PVT-collectors with one-cover and twocovers. On the other hand uncovered PVT-collector shows lower thermal efficiency compared to the covered by glass sheet PVT-collectors. So it would be reasonable to design the uncovered PVT-collector system where at high electrical efficiency the thermal efficiency would be improved. Therefore in this paper we present the design of uncovered PVT-collector system where unlike to [13] the built-in storage water heater is installed.

Table 1: Transmission-absorption factors for the various design concepts (AM 1.5 spectrum) of sheet-and-tube PVT-collectors.

\begin{tabular}{|l|c|c|c|}
\hline Design concept of PVT-Collector & $\boldsymbol{\tau}_{\boldsymbol{\alpha}}$ & $\boldsymbol{\tau}_{\boldsymbol{\alpha w}}$ & $\boldsymbol{\tau}_{\mathbf{p v}}$ \\
\hline Uncovered sheet-and-tube & 0.78 & - & 1.00 \\
\hline One-cover sheet-and-tube & 0.74 & - & 0.92 \\
\hline Two-cover sheet-and-tube & 0.71 & - & 0.84 \\
\hline
\end{tabular}

\section{MATERIALS AND METHODS}

Figure 1a shows the design of a PVT-collector system consisting of a metallic support (1), standard PV module (2), sheet-and-tube water collector (3), and storage tank-heater (4). The water temperature in the metallic storage tank-heater was measured by thermometer (5). Wheels (6 and 7) allowed changing position of the PVT collector manually at the tracking mode of operation. In the front and two sides of the right-angle prism tank (4) the glazing was made (8) with air gap of $1 \mathrm{~cm}$ and the surface of the tank from outside was blackened for additional heating of water by solar radiation. The bottom, 
Kh. S. Karimov and M. Abid

back side and the top of the tank was covered by glass-wool and aluminum foil. The volume of water tank was 20 liters. Connecting PVT-collector and the tank pipes were insulated by glass-wool and aluminum foil. The cold water was filled in the system through inlet (9), the tap (10) served to release the hot water.

The dimensions of the PV module were $1.22 \times 0.305 \mathrm{~m}$ with a total area of $0.37 \mathrm{~m}^{2}$. PV module with crystalline silicon cells that was used in the PVT-collector system, inclination arrangement and absorbing plate is shown in Fig. 1b-d. The sheet-and-tube water collector's design mainly was similar to the described in [14]. Figure 2 shows the design of the collector. On copper sheet of size of $0.86 \times 0.25 \mathrm{~m}$ four parallel copper tubes were fixed by welding. The copper was selected due to high thermal conductivity ( 385 $\left.\mathrm{W} / \mathrm{m}^{\circ} \mathrm{C}\right)$ as compared to aluminum $\left(211 \mathrm{~W} / \mathrm{m}^{\circ} \mathrm{C}\right)$ and steel $\left(54 \mathrm{~W} / \mathrm{m}^{\circ} \mathrm{C}\right)$. The collector was insulated by glass-wool, covered by aluminum foil and plywood and fixed under PV module. Interfaces of PV module's back and collector's sheet were in good thermal contact as collector was squeezed to the back of the module. Table 2 shows geometrical parameters of the collectors: $W$ is distance between of the centers of neighboring tubes, $\mathrm{D}$ is external diameter of the tube, $\delta$ is thickness of the metallic absorbing plate. Internal diameter of the tubes used in the present work was $0.006 \mathrm{~m}$.

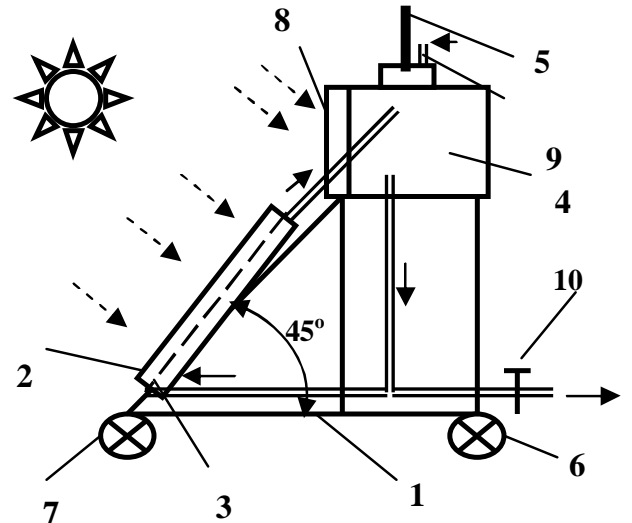

(a)

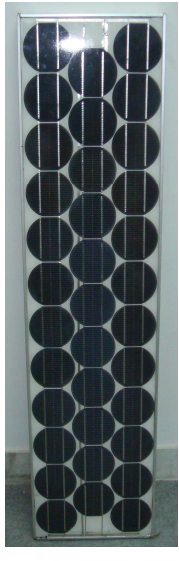

(b)

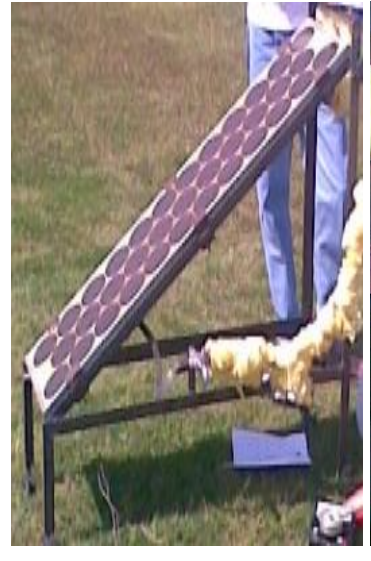

(c)

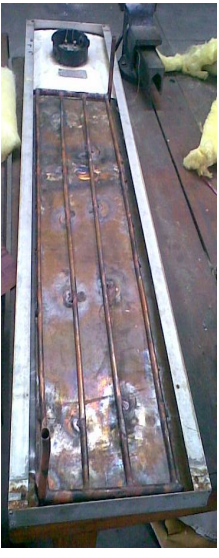

(d)

Fig. 1: (a) Design of PVT collector system, (b) PV Module, (c) Inclination setup, (d) Absorbing plate.

The latitude $(\varphi)$ of the place where the PVT-collector was investigated was 34 degree. Therefore an inclination angle $(\beta)$ of the PVT-collector to the horizontal plane used was 45 degree (usually $\beta=\varphi+11$ degree, $\varphi$ and $\varphi-11$ degree in winter, spring/autumn and summer respectively) as the experiments were conducted from February to April 2009 at GIK Institute during 7-9 hrs. The storage tank-heater played double role i.e. for storage of hot water and for water heating. The PVT-collector system could work in the fixed and tracking modes of operation. During investigations of PVT-collector in natural conditions, solar irradiance, voltage and current of PV module, ambient temperature and water temperature in storage tank were measured. 


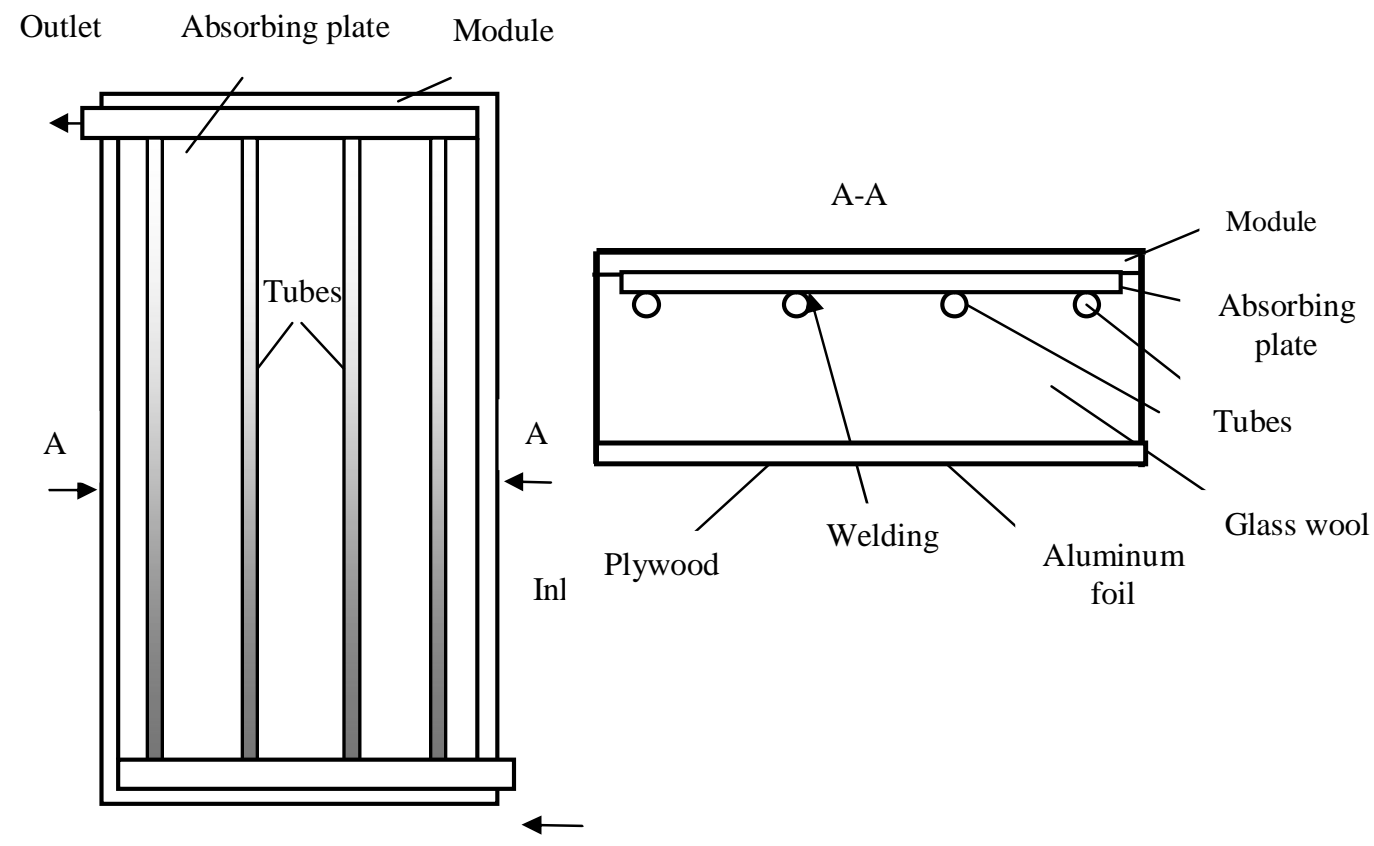

Fig. 2: Design of PVT Collector.

Table 2: Geometrical parameters of the sheet-and-tube water collectors.

\begin{tabular}{|l|l|l|l|}
\hline Reference & $\mathbf{W}(\mathbf{m})$ & $\mathbf{D}(\mathbf{m})$ & $\boldsymbol{\delta}(\mathbf{m})$ \\
\hline$[1]$ & 0.200 & 0.020 & 0.003 \\
\hline$[14]$ & 0.125 & 0.008 & 0.035 \\
\hline$[14]$ & 0.100 & 0.008 & 0.045 \\
\hline Present work & 0.060 & 0.008 & 0.003 \\
\hline
\end{tabular}

\section{RESULTS AND DISCUSSION}

Figure 3 a shows I-V characteristics of the module at average irradiance of $878 \mathrm{~W} / \mathrm{m}^{2}$ and inclination angle of $45^{\circ}$. The fill factor (FF) of the modules was 0.75 . Figure $3 b$ shows the output electric power at the tracking mode of operation measured during one of the cloudy day for one PV module. The output electric power $\left(P_{e l}\right)$ was calculated as per [2]:

$$
P_{e l}=I_{s c} V_{o c} F F
$$

where $I_{s c}$ and $V_{o c}$ are short circuit current and open-circuit voltage respectively. The average efficiency $\left(\eta_{e l}\right)$ of the conversion of solar energy into electric power was calculated as per [13]:

$$
\eta_{e l}=P_{e l} / G A
$$

where $G$ is irradiance in $\mathrm{W} / \mathrm{m}^{2}, A$ is area of the module. Efficiency $\left(\eta_{e l}\right)$ of $8 \%$ was calculated with average solar input power of $260 \mathrm{~W}$. 


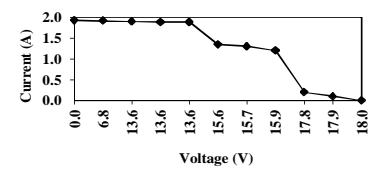

(a)

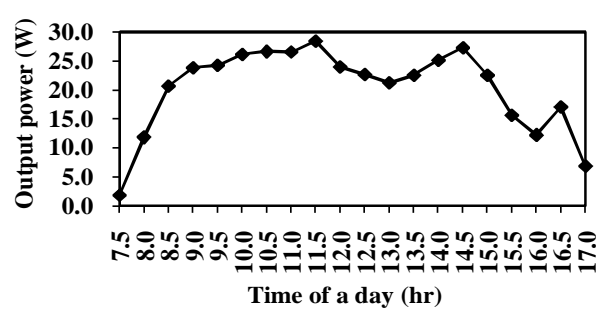

(b)

Fig. 3: (a) I-V characteristics of the module at irradiance of $878 \mathrm{~W} / \mathrm{m}^{2}$ and inclination angle of $45^{\circ}$, (b) Electric output power vs Day time for the PVT-collector system for a variable cloudy day.

Figure 4 shows the temperature of water $\left(T_{w}\right)$ in the tank versus day time $(t)$ relationship at the tracking mode of operation for the variable cloudy day. It is seen that the $T_{w}$ increased from $26{ }^{\circ} \mathrm{C}$ to $42{ }^{\circ} \mathrm{C}$. Average ambient temperature $\left(T_{a}\right)$ observed is $26{ }^{\circ} \mathrm{C}$.

The collector-tank-pipes loop is considered as a thermosyphon system where the water flow takes place due to the differences of the density of the hot and cold water [1]. At the same time, experimentally water temperature in the tank was measured where in the first approximation it was assumed that the water is in the static condition. Therefore thermal output power $\left(P_{T h}\right)$ for the case of static mass can be calculated as [1]:

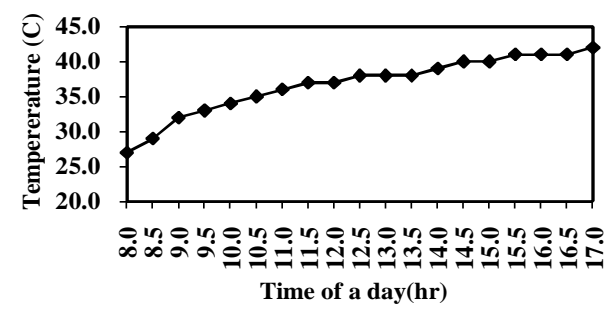

Fig. 4: The temperature of water in the tank vs day time for a variable cloudy day.

$$
P_{T h}=m c\left(d T_{w} / d t\right)
$$

where $m$ is a mass of water, $c$ is specific heat capacity. By evaluation of the average $d T_{w} / d t$ from Fig. 4, $P_{T h}$ was calculated and finally the efficiency of solar energy was converted into the thermal power as:

$$
\eta_{t h}=P_{T h} / G A
$$

$\eta_{t h}$ of $15 \%$ was calculated and may be considered the minimum as the water was not taken from tank during a day i.e. the total mass of water was constant during a day. If the tank's water is used several times a day, definitely the efficiency will increase. In the case of fixed mode of operation, without tracking, the experiments were conducted in variable cloudy day during $6 \mathrm{hrs}$, hence; it was observed that at the input power of $290 \mathrm{~W}$ the maximum temperature of water was almost $35{ }^{\circ} \mathrm{C}$ at the average ambient temperature of $28{ }^{\circ} \mathrm{C}$. The efficiencies of solar energy conversion into electric and thermal powers 
Kh. S. Karimov and M. Abid

calculated were $7 \%$ and $13 \%$ respectively. At the tracking mode of operation the efficiencies of solar energy conversion into electric and thermal powers calculated were $8 \%$ and $15 \%$ respectively. In this case the experiments were conducted during $9.5 \mathrm{hrs}$. Different duration of daily experiments was due to the variable clouds in February to April, 2009. At the same duration of experimental days and clear sky the efficiency of the tracking system is approximately $30 \%$ more than the fixed system [15].

In [13] annual thermal (24\%) and electrical (7.6\%) efficiencies were calculated for the case of uncovered sheet-and-tube PVT-collector system. The electrical efficiency is approximately the same as obtained in the present study, but the thermal efficiency is higher. The reasons of this is in the intensity of radiations, ambient temperature, construction of collector etc., and mainly maybe due to the approaches that were used for the calculations of the thermal power and accordingly the efficiency. In [13] the thermal power was calculated by:

$$
P T h=c(T 2-T 1) d m / d t
$$

where $d m / d t$ is mass flow through the collector in a unit of time and $T 1$ and $T 2$ are the temperatures of water in the inlet and outlet of the collector. Table 3 shows the efficiencies for the PVT-collectors design concepts: annual average efficiencies for the systems described in [13] and average efficiency for the February-April 2009 for the designed PVT-collectors presented in this study.

Table 3: Average efficiencies for the PVT-collectors design concepts [13].

\begin{tabular}{|l|c|c|}
\hline System & Thermal Efficiency & Electrical Efficiency \\
\hline PV & - & $7.2 \%$ \\
\hline $\begin{array}{l}\text { Sheet and tube PVT- } \\
\text { collector uncovered }\end{array}$ & $24 \%$ & $7.6 \%$ \\
\hline $\begin{array}{l}\text { Sheet and tube PVT- } \\
\text { collector 1 cover }\end{array}$ & $35 \%$ & $6.6 \%$ \\
\hline $\begin{array}{l}\text { Sheet and tube PVT- } \\
\text { collector 2 covers }\end{array}$ & $38 \%$ & $5.8 \%$ \\
\hline Present work & $15 \%$ & $8.0 \%$ \\
\hline
\end{tabular}

\section{CONCLUSION}

The uncovered sheet-and-tube PVT-collector system worked successfully in both the fixed and tracking modes of operation. During investigations of PVT-collector in natural conditions, solar irradiance, voltage and current of PV module, ambient temperature and water temperature in storage tank were measured. Average thermal and electrical powers of the PVT-collector system at the tracking mode of operation observed were $39 \mathrm{~W}$ and 21 $\mathrm{W}$, with efficiencies of $15 \%$ and $8 \%$ respectively at the input power of $260 \mathrm{~W}$. The maximum temperature of the water obtained was $42{ }^{\circ} \mathrm{C}$. Whereas at at the fixed mode of operation the efficiencies of solar energy conversion into electric and thermal powers calculated were $7 \%$ and $13 \%$ respectively at the input power of 290 W.The system was 
Kh. S. Karimov and M. Abid

observed efficient for low-temperature applications. The PVT-collector system may be used as a prototype for design of PVT-collector system for domestic application, teaching aid and for demonstration purposes. The output power of the PVT-collector system can be increased easily by increase of the number of PVT-collector units.

\section{ACKNOWLEDGEMENTS}

The authors acknowledge Pakistan Science Foundation for funding to complete this project and GIK Institute for support to carry out this research work. The authors are thankful to A. Iftikhar and H. Safeer for their help in fabrication of the PVT-collector system and experimental work.

\section{REFERENCES}

[1] Twidell ,J.W. and Weir, A.D. Renewable Energy Resources. E \& F.N. Spon, London, 1986.

[2] Markvart T., Solar Electricity .John Wiley \& Sons, New York, 2000.

[3] Russell T., Beall J., Lofersky J.J., Roessler B., Dobbins R., Shewchun J., Krikorian J., Case C., Doodlesack G., Oates W. Proceedings of IEEE Photovoltaic Specialists Conference, 1981.

[4] Hendrie S.D. Report MIT Lincoln laboratory, 1982.

[5] Bergene T., Lovvik O.M. Solar Energy, 55 (6), (1995), pp.453-462.

[6] Tripanagnostopoulos Y., Nousia T., Yianoulis P.Solar Energy, 72 (3), (2002), pp. 217-234.

[7] Rockendorf G., Sillman R., Podlowski L., Litzenburger B. Proceedings of ISES 1999 Solar World Congress, July 4-9, Jerusalem, Israel.

[8] Sorensen B. Proceedings of 17th European Photovoltaic Solar Energy Conference, October 22-26, Munich, Germany, 2001.

[9] Sandnes B., Rekstad J. Solar Energy 72 (1), (2002), pp. 63-73.

[10] Leenders F., Schaap A.B., van der Ree B.C.G., van Helden W.G.J. Proceedings of Eurosan 2000, Copenhagen, Denmark.

[11] Bakker M., Zondag H.A., van Helden W.G.J. Proceedings of PV in Europe-From PV Technology to Energy Solutions Conference and Exhibition, October 7-11, Rome, Italy, 2002.

[12] Bazilian M.D., Prasad D. Proceedings of Eurosun 2000, Copenhagen, Denmark.

[13] Zondag H.A., de Vries D.W., van Helden W.G.J., van Zolingen R.J.C., van Steenhoven A.A. Solar Energy, 74 (2003) , pp. 253-269.

[14] Tiwari G.N. Solar Energy Fundamentals, Design, Modeling and Application. Narosa Publishing House, New Delhi, India, 2004.

[15] Karimov Kh.S., Saqib M.A., Akhter P., Ahmed M.M., Chattha J.A., Yousafzai S.A. Solar Energy Materials \& Solar Cells. 